\title{
Disease resistance of pacu Piaractus mesopotamicus (Holmberg, 1887) fed with $\beta$-glucan
}

\author{
Biller-Takahashi, JD. ${ }^{a *}$, Takahashi, LS. ${ }^{b}$, Marzocchi-Machado, CM. , \\ Zanuzzo, FS. ${ }^{d}$ and Urbinati, EC. ${ }^{a, d}$ \\ aFaculdade de Ciências Agrárias e Veterinárias, Universidade Estadual Paulista - UNESP, \\ Via de Acesso Prof. Paulo Donato Castellane, s/n, CEP 14884-900, Jaboticabal, SP, Brazil \\ ${ }^{\text {b}}$ Faculdade de Zootecnia, Universidade Estadual Paulista - UNESP, Rod. Cmte João Ribeiro de Barros, \\ Km 651, Bairro das Antas, CEP 17900-000, Dracena, SP, Brazil \\ ${ }^{c}$ Faculdade de Ciências Farmacêuticas de Ribeirão Preto,Universidade de São Paulo -USP, \\ Avenida dos Bandeirantes, 3900, Monte Alegre, CEP 14040-903, Ribeirão Preto, SP, Brazil \\ ${ }^{\mathrm{d}}$ Centro de Aquicultura da UNESP - CAUNESP, Universidade Estadual Paulista - UNESP, \\ Via de Acesso Prof. Paulo Donato Castellane, s/n, CEP 14884-900, Jaboticabal, SP, Brazil \\ *e-mail: jaque.biller@yahoo.com.br
}

Received: July 31, 2012 - Accepted: May 9, 2013 - Distributed: August 31, 2014

(With 5 figures)

\begin{abstract}
Effects of $\beta$-glucan on innate immune responses and survival were studied in pacu experimentally infected with Aeromonas hydrophila. Fish fed diets containing $0,0.1 \%$ and $1 \% \beta$-glucan were injected with $A$. hydrophila. $\beta$-glucan enhanced fish survival in both treated groups ( $26.7 \%$ and $21.2 \%$ of the control, respectively). Leukocyte respiratory burst and alternative complement pathway activities were elevated after bacterial challenge regardless the $\beta$-glucan concentration. Lysozyme activity was higher after infection and showed a gradual increase as $\beta$-glucan concentration increased. A significant elevation in WBC count was observed either after bacterial challenge or by influence of $\beta$-glucan separately. The same response was observed in the number of thrombocytes, lymphocytes, eosinophils, LG-PAS positive cell and monocytes. It can be concluded that feeding pacu with $\beta$-glucan can increase protection against $A$. hydrophila, due to changes in non-specific immune responses.
\end{abstract}

Keywords: immunology, complement system, innate immunity, lysozyme, respiratory burst activity of leukocytes.

\section{Resistência à doença em pacu, Piaractus mesopotamicus (Holmberg, 1887), alimentados com $\beta$-glucana}

\section{Resumo}

Os efeitos da $\beta$-glucana sobre as respostas imunes inatas e a sobrevivência foram estudados em pacu experimentalmente infectado com Aeromonas hydrophila. Peixes alimentados com dietas contendo $0,1 \%$ e $1 \%$ de $\beta$-glucana foram injetados com 1 x $10^{8}$ CFU de $A$. hydrophila após 7 dias de alimentação. A sobrevivência de peixes foi maior nos dois grupos tratados em comparação ao grupo controle (26,7\% e 21,2\%, respectivamente). A atividade respiratória de leucócitos e a atividade hemolítica do complemento - via alternativa estavam elevadas após desafio bacteriano independentemente da concentração de $\beta$-glucana. A atividade de lisozima foi maior após a infecção e mostrou um aumento gradual de acordo com a concentração do imunoestimulante. Observou-se um aumento significativo na contagem de leucócitos totais após o desafio bacteriano e influência de $\beta$-glucana. A mesma resposta foi observada para trombócitos, linfócitos, eosinófilos, leucócito PAS positivo e monócitos. Com exceção de neutrófilos, que diminuíram frente ao mais alto nível do imunoestimulante e não se alteraram após a infecção, as outras células aumentaram após a exposição à $A$. hydrophila. A $\beta$-glucana não afetou os níveis de proteína total do soro, que aumentaram após o desafio bacteriano. Conclui-se que a administração de $\beta$-glucana em pacu pode aumentar a proteção contra $A$. hydrophila, por alterações nas respostas imunes de não-específicas.

Palavras-chave: imunologia, sistema complemento, imunidade inata, lisozima, atividade respiratória de leucócitos. 


\section{Introduction}

Recently aquaculture has developed a promising scenario for this segment of agriculture worldwide. However with intensive fish farming systems, the culture methods have become more intensive in order to obtain higher production resulting in immune deficiency that increase fish susceptibility to opportunistic pathogens. In this way, disease outbreaks have been shown as a limiting factor in intensive cultures (Zhou et al., 2010; Tort, 2011).

Among the pathogens in aquaculture, the Gram-negative bacteria $A$. hydrophila promotes the motile aeromonad septicaemia disease that has prompt uncountable economic losses in marine and freshwater aquaculture (KesarcodiWatson et al., 2008). As well in Brazil, A. hydrophila is one of the most important pathogens described on aquaculture farms (Godoy et al., 2008). Besides the limited number of government-approved antibiotics or chemotherapeutics in order to overcome bacterial disease, there is misuse that results in the appearance of antibiotic-resistant pathogens so that the impact of the antibiotic use in fish farming on the environment and on human health has become a major concern and therefore it is not a suitable alternative for the future (FAO, 2002; Andrews et al., 2009).

As an alternative for disease management in fish farming, attention has been addressed to immunity manipulation throughout the administration of functional nutrients such as immunostimulants that are safe for animals and humans, so that several products, including yeast glucan, have been tested in many fish (Sakai, 1999; Mouriño et al., 2012). Glucan is known to enhance the innate immunity and resistance against pathogenic bacteria in fish. Additionally, fish treated with $\beta$-glucan have shown enhanced phagocytic cell activity as well as enhanced lysozyme and complement activities (Engstad et al., 1992; Ai et al., 2007).

There are a few studies that report on immune manipulation of Brazilian species such as in pacu (Piaractus mesopotamicus) (Teleostei: Characidae) which is one of the most important freshwater fish farmed in Brazil (Jatobá et al., 2008; Biller-Takahashi et al., 2012; Mouriño et al., 2012; Biller-Takahashi et al., 2013). However, its farming has been facing disease threats and little information is available on the use of immunostimulants or the effects of bacterial infection in general Brazilian aquaculture (Garcia et al., 2007; Martins et al., 2009a; Biller-Takahashi et al., 2014). In the light of these facts, the purpose of this study was to evaluate the effect of oral administration of $\beta$-glucan on disease resistance of pacu experimentally infected with A. hydrophila.

\section{Material and Methods}

A total of $180 \mathrm{fish}(60.1 \pm 7.5 \mathrm{~g} ; 14.5 \pm 0.7 \mathrm{~cm})$ were distributed in nine $200 \mathrm{~L}$ tanks (20 fish per tank) with a continuous water flow system. The water was aerated with compressed air diffused through air stones. Fish were allowed to acclimatize for 20 days prior to the experimental feeding, being fed to apparent satiation with a commercial diet ( $28 \%$ protein, $3 \%$ fat, $1 \%$ fiber and $\beta$-glucan free) twice a day. The water quality parameters monitored daily were: temperature $26.07 \pm 0.39^{\circ} \mathrm{C}$; dissolved oxygen $5.66 \pm 0.57 \mathrm{mg} \mathrm{L}^{-1}$, measured with YSI 55 Oximeter, and $\mathrm{pH} 7.64 \pm 0.09$ measured with Corning $\mathrm{pH}$ meter.

Fish were distributed as follows: fish fed control diet (commercial diet $\beta$-glucan free), fish fed diet containing $0.1 \% \beta$-glucan and diet containing $1 \% \beta$-glucan. Each dietary treatment was randomly assigned to three tanks. The experimental diets were prepared using the commercial diet to which $\beta$-glucan (Macrogard $\AA$, Biorigin, Sao Paulo, Brazil) was included.

Seven days after feeding, fish were intraperitonially injected with washed cells of $A$. hydrophila, a strain from Laboratório de Patologia de Organismos Aquáticos (LAPOA-CAUNESP-Jaboticabal) (Genbank identification as ATCC 7966-http://www.ncbi.nlm.nih.gov/genbank/), prepared as described by Garcia et al. (2007). Fifty four fish per treatment were injected with $1 \times 10^{8} \mathrm{CFU} \mathrm{mL}^{-1}$ of live A. hydrophila. Mortality and clinical signs were recorded twice a day for 15 days and cumulative survival rate was calculated as follow: $\operatorname{CSR}(\%)=(1$ - number of mortality / total number of fish) x 100 .

Two samplings were carried out: before the challenge and one week after the challenge. At both samplings, six fish per treatment were anesthetised (benzocaine, $0.1 \mathrm{~g} \mathrm{~L}^{-1}$ ) and blood was collected for hematology and immune analyses. Total leukocytes count (WBC) and differential leukocytes count were determined in blood smears stained by May-Grünwald-Giemsa (Rosenfeld, 1947). WBC number was calculated using the formula: leukocytes $/ \mu 1$ $=$ (leukocyte number in the smear $\mathrm{x}$ erythrocyte number/ $\mu 1) / 2,000$ erythrocytes counted in the smear, as described by Ishikawa et al. (2008).

The assay of leucocytes respiratory burst activity was carried out using total blood according to BillerTakahashi et al. (2013). The optical density (OD) of the final solution was measured at $540 \mathrm{~nm}$. After serum extraction, lysozyme activity was measured as described by Ellis (1990), with partial modifications (Abreu et al., 2009). Results were expressed in units of lysozyme $\mathrm{ml}^{-1}$ serum. One unit is defined as the amount of sample causing a reduction in absorbance of $0.001 \mathrm{~min}^{-1}$ at $450 \mathrm{~nm}$ compared to the control (Micrococcus lysodeikticus suspension without serum). The hemolytic complement activity was measured using the alternative complement pathway (ACP50) according to Biller-Takahashi et al. (2012). The hemolysis was estimated by measuring the optical density (OD) of the supernatant at $700 \mathrm{~nm}$ for $10 \mathrm{~min}$. The value of $50 \%$ hemolysis was calculated from the hemolysis curves of diluted sera. Total serum protein was determined by biuret method (Labtest Kit).

Differences among treatments and the challenge effect were assessed using two-way ANOVA. The comparison of any two mean values was performed using Duncan's multiple range test $(p<0.05)$. Results are presented as means \pm standard error and were analysed using the SAS statistical program (9.2). 


\section{Results}

Dietary $\beta$-glucan improved survival in both $0.1 \%$ and $1 \% \beta$-glucan treated fish (Figure 1). Sampled fish presented red spotted skin lesions of varied degree along their bodies, ulcers, especially in the bacterium injection site, mild exophthalmia, and abdominal swelling.

Fish fed with $1 \% \beta$-glucan showed increased WBC, as well as the challenged fish $(\mathrm{p}<0.05)$ separately (Table 1). Among the leukocytes, lymphocytes were predominant (Table 1). $\beta$-glucan increased thrombocytes, lymphocytes, eosinophils, special granulocytic cells, and monocytes $(p<0.05)$. The cells number increased as the immunostimulant doses increased. Other leukocytes, the neutrophils declined in fish fed with $1 \% \beta$-glucan. The number of all types cells have increased after the exposure to the bacterium $(p<0.05)$, except for the neutrophils that did not change $(\mathrm{p}>0.05)$.

The leukocytes respiratory burst activity was higher after challenge with $A$. hydrophila $(\mathrm{p}<0.05)$ independent of the $\beta$-glucan level (Figure 2). The $\beta$-glucan diet did not affect significantly the leukocytes respiratory burst activity in spite of a trend of increase as the $\beta$-glucan level increased. The serum lysozyme activity was significantly higher due to the challenge and $\beta$-glucan effects, as seen in a gradual increase observed as the immunostimulant increased $(\mathrm{p}<0.05)$ (Figure 3).

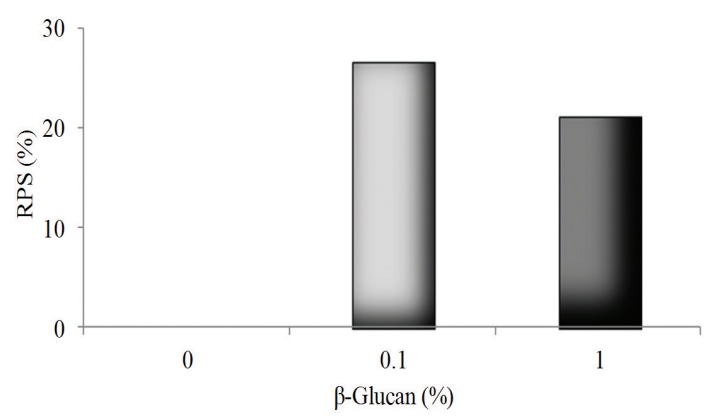

Figure 1. Relative percentage of survival (RPS) of pacu fed $\beta$-glucan challenged with $A$. hydrophila.
Fish fed with $1 \% \beta$-glucan diet had higher lysozyme activity compared to control fish $(\mathrm{p}<0.05)$ (Figure 3$)$. Dietary $\beta$-glucan treatments did not induce significant changes $(p>0.05)$ in the haemolitic activity of ACP50 (Figure 4). However, the lowest mean ACP50 was obtained in infected fish serum indicating higher hemolytic activity of the alternative complement pathway $(\mathrm{p}<0.05)$, once there are an inverse correlation between these two parameters (Figure 4). The total serum protein level was not affected by $\beta$-glucan $(\mathrm{p}>0.05)$ (Figure 5) although it had increased $(\mathrm{p}<0.05)$ in fish after the $A$. hydrophila challenge.

\section{Discussion}

The immunostimulant effect of $\beta$-glucan has been well established due to the existence of specific receptors at the defense cells surface, like macrophages and other phagocytes, and the activation of cells such as macrophages, neutrophils, monocytes, natural killer cells and dendritic cells throughout specific receptors prompt pro or antiinflammatory effects in dependence of the receptor triggered (Chan et al., 2009; Goodridge et al., 2009; Kiron, 2012).

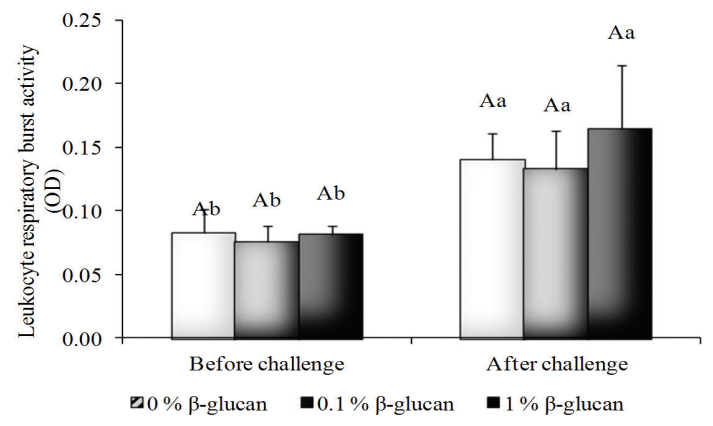

Figure 2. Leukocytes respiratory burst activity of pacu fed $\beta$-glucan challenged with $A$. hydrophila. Lowercase letters indicate significant difference among treatments before and after challenge, uppercase letters indicate significant difference among $\beta$-glucan treatments in each challenge at $\mathrm{p}<0.05$.

Table 1. White blood cell (WBC) and differential WBC count of pacu fed $\beta$-glucan challenged with A. hydrophila1 $\left(\mathrm{x} 10^{3} \mu \mathrm{L}^{-1}\right) 1$.

\begin{tabular}{lccccc}
\hline & \multicolumn{3}{c}{ Experimental diets } & \multicolumn{2}{c}{ Samplings } \\
\hline WBC & $\mathbf{0 . 0}$ & $\mathbf{0 . 1}$ & $\mathbf{1 . 0}$ & Before challenge & After challenge \\
Thrombocytes & $46.79 \pm 4.12 \mathrm{~B}$ & $54.43 \pm 3.73 \mathrm{~B}$ & $67.94 \pm 6.17 \mathrm{~A}$ & $46.28 \pm 2.44 \mathrm{~b}$ & $69.57 \pm 4.00 \mathrm{a}$ \\
Lymphocytes & $28.55 \pm 2.04 \mathrm{~B}$ & $17.49 \pm 1.98 \mathrm{~B}$ & $25.76 \pm 4.22 \mathrm{~A}$ & $14.98 \pm 1.22 \mathrm{~b}$ & $26.25 \pm 3.04 \mathrm{a}$ \\
Neutrophils & $0.61 \pm 0.11 \mathrm{AB}$ & $0.79 \pm 0.17 \mathrm{~A}$ & $0.22 \pm 0.12 \mathrm{~B}$ & $0.48 \pm 0.56 \mathrm{a}$ & $0.77 \pm 0.21 \mathrm{a}$ \\
Eosinophils & $0.36 \pm 0.36 \mathrm{~B}$ & $0.50 \pm 0.15 \mathrm{AB}$ & $0.71 \pm 0.13 \mathrm{~A}$ & $0.33 \pm 0.38 \mathrm{~b}$ & $0.78 \pm 0.16 \mathrm{a}$ \\
LG-PAS $^{1}$ & $0.14 \pm 0.73 \mathrm{~B}$ & $0.32 \pm 0.46 \mathrm{AB}$ & $0.78 \pm 0.43 \mathrm{~A}$ & $0.16 \pm 0.50 \mathrm{~b}$ & $0.71 \pm 0.27 \mathrm{a}$ \\
Monocytes & $1.18 \pm 0.26 \mathrm{~B}$ & $1.78 \pm 0.52 \mathrm{AB}$ & $2.27 \pm 0.5 \mathrm{~A}$ & $0.88 \pm 0.12 \mathrm{~b}$ & $3.09 \pm 0.48 \mathrm{a}$ \\
\hline
\end{tabular}

${ }^{1}$ Means \pm s.e.m in the column with different letters denotes significant differences at $\mathrm{p}<0.05$; Lowercase letters indicate significant difference between before and after challenge; Uppercase letters indicate significant difference among $\beta$-glucan treatments. LG-PAS $=$ Granular leukocyte PAS positive. 
In this work, the oral administration of $\beta$-glucan to pacu activated receptors since its immune status improved as indicated by enhanced immune responses and increased survival of fish after infection with $A$. hydrophila. In previous studies, $\beta$-glucan has been shown to reduce mortality in fish challenged with A.salmonicida (Nikl et al.,

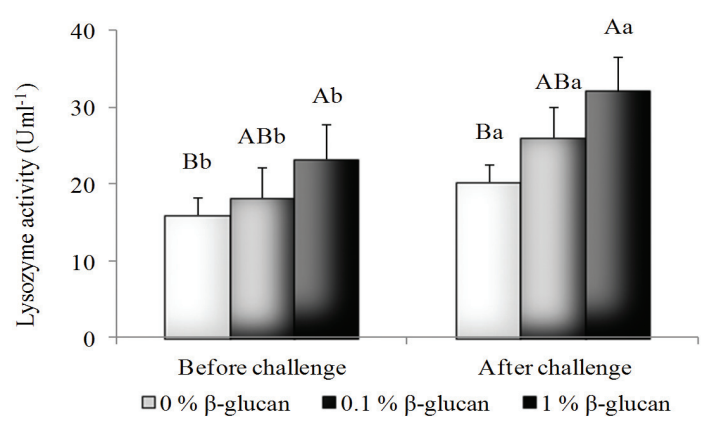

Figure 3. Serum activity of lysozyme of pacu fed $\beta$-glucan challenged with $A$. hydrophila. Lowercase letters indicate significant difference among treatments before and after challenge, uppercase letters indicate significant difference among $\beta$-glucan treatments in each challenge at $p<0.05$.

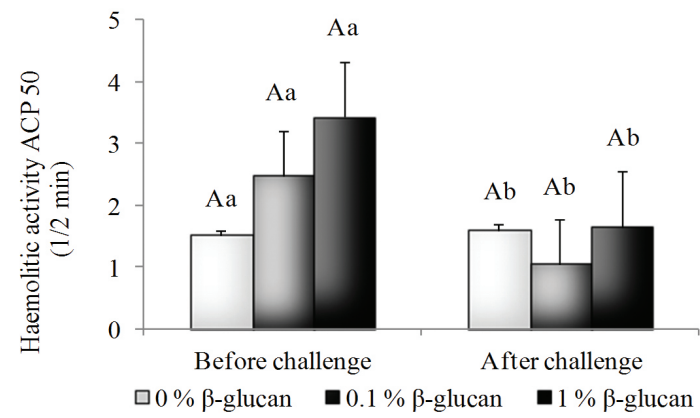

Figure 4. Haemolitic activity of alternative complement pathway $\left(\mathrm{ACP}_{50}\right)$ of pacu fed $\beta$-glucan challenged with A. hydrophila. Lowercase letters indicate significant difference among treatments before and after challenge, uppercase letters indicate significant difference among $\beta$-glucan treatments in each challenge at $\mathrm{p}<0.05$.

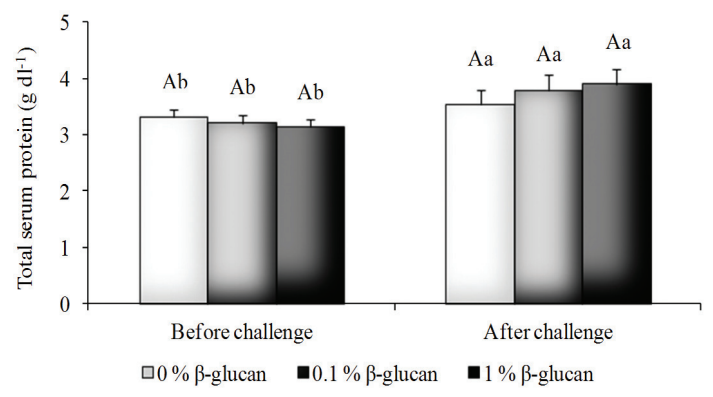

Figure 5. Total serum protein of pacu fed $\beta$-glucan challenged with $A$. hydrophila. Lowercase letters indicate significant difference among treatments before and after challenge, uppercase letters indicate significant difference among $\beta$-glucan treatments in each challenge at $p<0.05$.
1993), A. hydrophila (Selvaraj et al., 2005), Streptococcus iniae(Russo et al., 2006) and Vibrio harveyi (Ai et al., 2007) but failed to protect turbot (Scophthalmus maximus Rafinesque 1810) against Enterococcus sp. (Toranzo et al., 1995) or against $V$. anguillarum (Ogier de Baulny et al., 1996), and channel catfish (Ictaurus punctatus Rafinesque 1818) against Edwardsiella ictaluri (Duncan and Klesius, 1996). The increased survival observed in pacu can be correlated with some immune responses assayed such as the WBC count, that increased either in pacu fed with $\beta$-glucan or in fish injected with $A$. hydrophila since leukocytes are considered to be a health indicator because of its role in cellular immunity. In fact, the highest WBC count has already been correlated with the best immunity enhancement in treated fish (Jha et al., 2007; Andrews et al., 2009).

Thrombocytes and lymphocytes (eosinophils, LG-PAS and monocytes) increased in both experimental conditions, except for neutrophils, that decreased when fish were fed $\beta$-glucan and did not change after the infection. In the same way, carp injected with $\beta$-glucan also showed increased WBC count and the proportion of neutrophils and monocytes (Selvaraj et al., 2005), suggesting that $\beta$-glucan potentiated cellular immune defense of fish by inducing leukocyte proliferation. The phagocytic function of monocytes and later the macrophages, as well as neutrophils, are important in preventing the establishment of bacterial infection in host tissue (Yoshida et al., 1995). A rise in WBC count was also described in turbot in response to $\beta$-glucans as well corroborating this assay (Ogier de Baulny et al., 1996; Martins, et al. 2009b; Jerônimo, et al., 2011).

Leukocyte respiratory burst activity of pacu was elevated after challenge and was not affected by $\beta$-glucan administration. The first response could be associated with the response of monocytes and neutrophils that increased significantly after infection. In case of the $\beta$-glucan treated fish ( $1 \% \beta$-glucan) monocytes also increased but there was a concomitant decrease of neutrophils. According to Anderson and Siwicki (1995), neutrophils and monocytes are responsible for the production of large quantities of superoxide anion in defense against pathogens. Contrary to the present study, $\beta$-glucan enhanced the production of superoxide anion by macrophages in several other fish species (Yoshida et al., 1995; Ogier de Baulny et al., 1996; Ai et al., 2007). However, these studies differ on the experimental protocol (type of $\beta$-glucan, dosage or time of administration).

Serum lysozyme activity was enhanced in A. hydrophila challenged pacu 7 days after oral $\beta$-glucan feeding suggesting that different immunological parameters respond differently to $\beta$-glucan. Lysozyme is a mucolytic enzyme of leukocytic origin which acts against parasitic, bacterial and viral pathogens (Ai et al., 2007). According to Engstad et al. (1992), immunostimulants increase the lysozyme activity through the stimulation of leukocytes. Those authors have suggested that $\beta$-glucan enhanced the serum lysozyme activity in Atlantic salmon due to an increased number of phagocytes secreting lysozyme, and/or an increased 
amount of lysozyme synthesized by these cells. Palić et al. (2006) have shown in fathead minnows (Pimephales promelas Rafinesque, 1820) that dietary $\beta$-glucan increased phagocytes degranulation in unstressed fish, and prevented a decrease in acutely stressed fish.

The highest hemolytic activity of complement system was obtained in infected pacu without effects of oral $\beta$-glucan. Similarly, oral administration of $\beta$-glucan did not induce changes in alternative complement pathway in previous studies (Ogier de Baulny et al., 1996; Ai et al., 2007).

The increase of the total serum protein in pacu after bacterial challenge could be associated with the increased lysozyme and complement activity. The pool of serum proteins includes many soluble and membrane-bound proteins of the complement system among others.

In conclusion, feeding $\beta$-glucan up to 7 days significantly increased resistance against $A$. hydrophila, as well the leukocytes production and lysozyme activity of pacu suggesting benefits of the use of this immunostimulant in the farming of this species. The $\beta$-glucan incorporation in food to promote pathogens resistance can be an alternative to antibiotics administration. A dose of $0.1 \%$ of $\beta$-glucan during 10 days was efficient to promote higher survival, while a dose of $1 \%$ of $\beta$-glucan promoted higher benefits in WBC and lysozyme activity. Nevertheless, there is a lack of information about the period of remaining protection as well as the effects of a long period of $\beta$-glucan administration on immune system of pacu.

\section{Acknowledgements}

This study received funding from $\mathrm{CNPq}$ (Conselho Nacional de Desenvolvimento Científico e Tecnológico) and CAPES (Coordenação de Aperfeiçoamento de Pessoal de Nível Superior).

\section{References}

ABREU, JS., MARZOCCHI-MACHADO, CM., URBACZEK, AC., FONSECA, LM. and URBINATI, EC., 2009. Leukocytes respiratory burst and lysozyme level in pacu (Piaractus mesopotamicus Holmberg, 1887). Revista Brasileira de Biologia = Brazilian Journal of Biology, vol. 69, no. 4, p. 1133-1139. http://dx.doi. org/10.1590/S1519-69842009000500018. PMid:19967185

AI, Q., MAI, K., ZHANG, L., TAN, B., ZHANG, W., XU, W. and LI, H., 2007. Effects of dietary $\beta-1,3$ glucan on innate immune response of large yellow croaker, Pseudosciaena crocea. Fish \& Shellfish Immunology, vol. 22, no. 4, p. 394-402. http://dx.doi. org/10.1016/j.fsi.2006.06.011. PMid:16928452

ANDERSON, DP. and SIWICKI, AK., 1995. Basic haematology and serology for fish health programs. In SHARIFF, M., ARTHUR, J.R. and SUBASINGHE, R.P. (Eds.). Diseases in Asian aquaculture II. Fish Health Section. Manila, Philippines: Asian Fisheries Society. p. 185-202.

ANDREWS, SR., SAHU, NP., PAL, AK., PAL, AK. and KUMAR, S., 2009. Haematological modulation and growth of Labeo rohita fingerlings: effect of dietary mannan oligosaccharide, yeast extract, protein hydrolysate and chlorella. Aquaculture and
Research, vol. 41, no. 1, p. 61-69. http://dx.doi.org/10.1111/j.13652109.2009.02304.x

BILLER-TAKAHASHI, J., MONTASSIER, H., TAKAHASHI, L. and URBINATI, E., 2014. Proposed method for agglutinating antibody titer analysis and its use as indicator of acquired immunity in pacu, Piaractus mesopotamicus. Revista Brasileira de Biologia = Brazilian Journal of Biology, vol. 74, no. 1, p. 238-242. http:// dx.doi.org/10.1590/1519-6984.21312. PMid:25055109

BILLER-TAKAHASHI, JD., TAKAHASHI, LS., MARZOCCHIMACHADO, CM., ZANUZZO, FS., SABIONI, RE. and URBINATI, EC., 2012. Hemolytic activity of alternative complement pathway as an indicator of innate immunity in pacu (Piaractus mesopotamicus). Revista Brasileira de Zootecnia, vol. 41, no. 2, p. 237-241. http:// dx.doi.org/10.1590/S1516-35982012000200001.

BILLER-TAKAHASHI, JD., TAKAHASHI, LS., SAITA, MV., GIMBO, RY. and URBINATI, EC., 2013. Leukocytes respiratory burst activity as indicator of innate immunity of pacu Piaractus mesopotamicus. Revista Brasileira de Biologia = Brazilian Journal of Biology, vol. 73, no. 2, p. 425-429. http://dx.doi.org/10.1590/ S1519-69842013000200026. PMid:23917573

CHAN, GC., CHAN, WK. and SZE, DM., 2009. The effects of beta-glucan on human immune and cancer cells. Journal of Hematology and Oncology, vol. 2, no. 2, p. 25. http://dx.doi. org/10.1186/1756-8722-2-25. PMid: 19515245

DUNCAN, PL. and KLESIUS, PH., 1996. Dietary immunostimulants enhance non-specific immune responses in channel catfish but not resistance to Edwardsiella ictaluri. Journal of Aquatic Animal Health, vol. 8, no. 3, p. 241-248. http://dx.doi.org/10.1577/15488667(1996)008<0241:DIENIR>2.3.CO;2.

ELLIS, AE., 1990. Lysozyme assays. In STOLEN, JS., FLETCHER, TC., ANDERSON, DP., ROBERSON, BS., MUISWINKEL, WB. (Eds.). Techniques in Fish Immunology. USA: SOS Publications. p. 101-103.

ENGSTAD, RE., ROBERTSEN, B. and FRIVOLD, E., 1992. Yeast glucan induces increase in lysozyme and complement-mediated haemolytic activity in Atlantic salmon blood. Fish \& Shellfish Immunology, vol. 2, no. 4, p. 287-297. http://dx.doi.org/10.1016/ S1050-4648(06)80033-1.

FOOD AND AGRICULTURE ORGANIZATION OF UNITED NATIONS - FAO, 2002. Antibiotics Residue in Aquaculture Products. The State of World Fisheries and Aquaculture. Rome, Italy: FAO, p. 74-82.

GARCIA, F., PILARSKI, F., ONAKA, EM., MORAES, FR. and MARTINS, ML., 2007. Hematology of Piaractus mesopotamicus fed diets supplemented with vitamins $\mathrm{C}$ and $\mathrm{E}$, challenged by Aeromonas hydrophila. Aquaculture (Amsterdam, Netherlands), vol. 271, no. 1-4, p. 39-46. http://dx.doi.org/10.1016/j.aquaculture.2007.06.021.

GODOY, DT., MIAN, GF., ZANOLO, R., YUHARA, TY., FARIA, FC. and FIGUEIREDO,H.C.P., 2008. Patterns of resistance to florfenicol and bicyclomycin in Brazilian strains of motile aeromonads. Aquaculture (Amsterdam, Netherlands), vol. 285, no. 1-4, p. 255-259. http://dx.doi.org/10.1016/j.aquaculture.2008.08.014.

GOODRIDGE, HS., WOLF, AJ. and UNDERHILL, DM., 2009. Beta-glucan recognition by the innate immune system. Immunological Reviews, vol. 230, no. 1, p. 38-50. http://dx.doi. org/10.1111/j.1600-065X.2009.00793.x. PMid:19594628

ISHIKAWA, NM., RANZANI-PAIVA, MJT. and LOMBARDI, JV., 2008. Metodologia para quantificação de leucócitos totais 
em peixes, Oreochromis niloticus. Archives of Veterinary Science, vol. 13 , no. 1, p. 54-63.

JATOBÁ, A., NASCIMENTO VIEIRA, F., BUGLIONE NETO, C., SILVA, BC., MOURIÑO, JLP., JERÔNIMO, GT., DOTTA, G. and MARTINS, ML., 2008. Utilização de bactérias ácido-lácticas isoladas do trato intestinal de tilapiadonilo como probiótico. Pesquisa Agropecuaria Brasileira, vol. 43, no. 9, p. 1201-1207. http://dx.doi.org/10.1590/S0100-204X2008000900015.

JERÔNIMO, GT., LAFFITTE, LV., SPECK, GM. and MARTINS, ML., 2011. Seasonal influence on the hematological parameters in cultured Nile tilapia from southern Brazil. Revista Brasileira de Biologia = Brazilian Journal of Biology, vol. 71, no. 3, p. 719-725. http://dx.doi.org/10.1590/S1519-69842011000400017. PMid:21881796

JHA, AK., PAL, AK., SAHU, NP., KUMAR, S. and MUKHERJEE, SC., 2007. Haemato-immunological responses to dietary yeast RNA, $\omega-3$ fatty acid and $\beta$-carotene in Catla catla juveniles. Fish \& Shellfish Immunology, vol. 23, no. 5, p. 917-927. http://dx.doi. org/10.1016/j.fsi.2007.01.011. PMid:17681812

KESARCODI-WATSON, A., KASPAR, H., LATEGAN, MJ. and GIBSON, L., 2008. Probiotics in aquaculture: the need, principles and mechanisms of action and screening processes. Aquaculture (Amsterdam, Netherlands), vol. 274, no. 1, p. 1-14. http://dx.doi. org/10.1016/j.aquaculture.2007.11.019.

KIRON, V., 2012. Fish immune system and its nutritional modulation for preventive health care. Animal Feed Science and Technology, vol. 173, no. 1-2, p. 111-133. http://dx.doi. $\operatorname{org} / 10.1016 /$ j.anifeedsci.2011.12.015.

MARTINS, ML., MYIAZAKI, DMY., TAVARES-DIAS, M., FENERICK JUNIOR, J., ONAKA, EM., BOZZO, FR., FUJIMOTO, RY. and MORAES, FR., 2009b. Characterization of the acute inflammatory response in the hybrid tambacu (Piaractus mesopotamicus male x Colossoma macropomum female) (Osteichthyes). Revista Brasileira de Biologia = Brazilian Journal of Biology, vol. 69, no. 3, p. 957-962. PMid:19802458.

MARTINS, ML., VIEIRA, FN., JERÔNIMO, GT., MOURIÑO, JLP., DOTTA, G., SPECK, GM., BEZERRA, AJM.,PEDROTTI, FS., BUGLIONE-NETO, CC. and PEREIRA JUNIOR, G., 2009a. Leukocyte response and phagocytic activity in Nile tilapia experimentally infected with Enterococcus sp. Fish Physiology and Biochemistry, vol. 35, no. 1, p. 219-222. http://dx.doi.org/10.1007/ s10695-008-9262-x. PMid:18777139

MOURIÑO, JLP., DO NASCIMENTO VIEIRA, F., JATOBÁ, AB., DA SILVA, BC., JESUS, GFA., SEIFFERT, WQ. and MARTINS, ML., 2012. Effect of dietary supplementation of inulin and W. cibaria on haemato-immunological parameters of hybrid surubim (Pseudoplatystoma sp). Aquaculture Nutrition, vol. 18, no. 1, p. 73-80. http://dx.doi.org/10.1111/j.1365-2095.2011.00879.x.

NIKL, L., EVELYN, TPT. and ALBRIGHT, LJ., 1993. Trials with an orally and immersion administrated $\beta-1,3$ glucan as an immunoprophylactic against Aeromonas salmonicida in juvenile chinook salmon Oncorhynchus tshawytscha. Diseases of Aquatic Organisms, vol. 17, no. 2, p. 1991-1996.
OGIER DE BAULNY, M., QUENTEL, C., FOURNIER, V., QUENTEL, C., FOURNIER, V., LAMOUR, F. and LE GOUVELLO, R., 1996. Effect of long-term oral administration of $\beta$-glucan as an immunostimulant or an adjuvant on some non-specific parameters of the immune response of turbot Scophthalmus maximus. Diseases of Aquatic Organisms, vol. 26, no. 4, p. 139-147. http://dx.doi. org/10.3354/dao026139.

PALIĆ, D., ANDREASEN, CB., HEROLT, DM., MENZEL, BW. and ROTH, JA., 2006. Immunomodulatory effects of $\beta$-glucan on neutrophil function in fathead minnows (Pimephales promelas Rafinesque, 1820). Developmental and Comparative Immunology, vol. 30, no. 9, p. 817-830. http://dx.doi.org/10.1016/j. dci.2005.11.004. PMid:16423394

ROSENFELD, G., 1947. Corante pancrômico para hematologia e citologia clínica. Nova combinação dos componentes do May-Grünwald e do Giemsa num só corante de emprego rápido. Memorias do Instituto Butantan, vol. 20, no. 1, p. 329-334.

RUSSO, R., YANONG, RPE. and MITCHELL, H., 2006. Dietary beta-glucans and nucleotides enhance resistance of redtail black shark (Epalzeorhynchos bicolor, fam. Cyprinidae) to Streptococcus iniae infection. Journal of the World Aquaculture Society, vol. 37, no. 3, p. 298-306. http://dx.doi.org/10.1111/j.17497345.2006.00040.x.

SAKAI, M., 1999. Current research status of fish immunostimulants. Aquaculture (Amsterdam, Netherlands), vol. 172, no. 1-2, p. 63-92. http://dx.doi.org/10.1016/S0044-8486(98)00436-0.

SELVARAJ, V., SAMPATH, K. and SEKAR, V., 2005. Administration of yeast glucan enhances survival and some non-specific and specific immune parameters in carp (Cyprinus carpio) infected with Aeromonas hydrophila. Fish \& Shellfish Immunology, vol. 19, no. 4, p. 293-306. http://dx.doi.org/10.1016/j.fsi.2005.01.001. PMid:15863011

TORANZO, AE., DEVESA, S., ROMALDE, JL., LAMAS, J., RIAZA, A., LEIRO, J. and BARJA, JL., 1995. Efficacy of intraperitoneal and immersion vaccination against Enterococcus sp. infection in turbot. Aquaculture (Amsterdam, Netherlands), vol. 134, no. 1-2, p. 17-27. http://dx.doi.org/10.1016/00448486(95)00038-4.

TORT, L., 2011. Stress and immune modulation in fish. Developmental and Comparative Immunology, vol. 35, no. 12, p. 1366-1375. http://dx.doi.org/10.1016/j.dci.2011.07.002. PMid:21782845

YOSHIDA, T., KRUGER, R. and INGLIS, V., 1995. Augmentation of non-specific protection in African catfish, Clarias gariepinus (Burchell) by the long-term oral administration of immunostimulants. Journal of Fish Diseases, vol. 18, no. 2, p. 195-198. http://dx.doi. org/10.1111/j.1365-2761.1995.tb00278.x.

ZHOU, X., TIAN, Z., WANG, Y. and LI, W., 2010. Effect of treatment with probiotics as water additives on tilapia (Oreochromis niloticus) growth performance and immune response. Fish Physiology and Biochemistry, vol. 36, no. 3, p. 501-509. http:// dx.doi.org/10.1007/s10695-009-9320-z. PMid:19363655 